\title{
Hematology of Nile tilapia (Oreochromis niloticus) subjected to anesthesia and anticoagulation protocols
}

\author{
Hematologia de tilápia do Nilo (Oreochromis niloticus) submetidas a \\ protocolos anestésicos e de anticoagulação
}

\author{
Nadia Cristine Weinert ${ }^{1 *}$; Julieta Volpato ${ }^{2}$; Ádson Costa ${ }^{3}$; Rozyanne Rosa Antunes ${ }^{3}$; \\ Aldo Camargo de Oliveira ${ }^{4}$; Cláudio Roberto Scabelo Mattoso ${ }^{5}$; Mere Erika Saito ${ }^{6}$
}

\begin{abstract}
Clinical hematology facilitates the diagnosis of disease and can act as a prognostic indicator of pathological conditions in fish. The aim of the present study was to evaluate hematological parameters of Nile tilapia (Oreochromis niloticus) subjected to different anesthetics and anticoagulants. Thirty apparently healthy fishes (average weight of $473 \pm 35.50 \mathrm{~g}$ and mean total length of $29.33 \pm 0.37 \mathrm{~cm}$ ), were selected from the local commercial fish farm in the Lages municipality (Santa Catarina, Brazil). The animals were randomly divided into three groups of 10 . In two groups, anesthesia was induced with eugenol $\left(70 \mathrm{mg} \cdot \mathrm{L}^{-1}\right)$ (EG) and Benzocaine hydrochloride $\left(100 \mathrm{mg} \cdot \mathrm{L}^{-1}\right)(\mathrm{BG})$, respectively. Anesthesia was not administered to fish of the third group (CG/control group). Blood samples were obtained by venipuncture of the caudal vessels and placed into microtubes containing sodium heparin or $\mathrm{Na}_{2}$ EDTA for further analysis. The results were analyzed by Sigma Stat for Windows, the paired t-test for significant differences between anticoagulants of the same group, and analysis of variance followed by the Tukey test for comparison of means between groups $(p \leq 0.05)$. Most of the observed changes in the erythrogram were significantly higher for the anticoagulant heparin and benzocaine group in comparison to the control group. However, the values obtained for the leukogram were significantly higher for all groups subjected to the $\mathrm{Na}_{2}$ EDTA anticoagulant, suggesting that heparin may cause cell clumping. The results suggest that the anesthetics under investigation effectively minimizes the effects of stress caused by handling and invasive procedures, and that the anticoagulant heparin causes less hemolysis in comparison to $\mathrm{Na}_{2}$ EDTA for Nile tilapia. Thus, the hematological variations attributed to different anesthetic protocols and/or different anticoagulants should be considered for the species Oreochromis niloticus.
\end{abstract}

Key words: Anesthetics, anticoagulants, hematology, Oreochromis niloticus, osmotic fragility

\section{Resumo}

A hematologia clínica é uma ferramenta que auxilia na realização do diagnóstico de doenças e pode atuar como um indicador prognóstico das condições patológicas de peixes. O objetivo deste estudo foi avaliar

\footnotetext{
${ }^{1}$ Médica Veterinária, M.e em Ciência Animal, Universidade do Estado de Santa Catarina, UDESC, Lages, SC, Brasil. E-mail: nadiaweinert@hotmail.com

${ }^{2}$ Médica Veterinária, Discente do Curso de Doutorado, UDESC, Lages, SC, Brasil. E-mail: jully_volps@hotmail.com

${ }^{3}$ Médicos Veterinários, Discentes do Curso de Mestrado em Ciência Animal, UDESC, Lages, SC, Brasil. E-mail: eggcosta@ hotmail.com; rozyantunes@hotmail.com

${ }^{4}$ Bioquímico, M.e em Ciência Animal, UDESC, Lages, SC, Brasil. E-mail: olivafarma@hotmail.com

5 Pós-Doutorando em Ciência Animal, Dr., Médico Veterinário, Dept ${ }^{\circ}$ de Clínica e Cirurgia Veterinárias, Escola de Veterinária, Universidade Federal de Minas Gerais, UFMG, Belo Horizonte, MG, Brasil. E-mail: crsmattoso@yahoo.com

${ }^{6}$ Prof $^{\mathrm{a}}$ Dr $^{\mathrm{a}}$, Dept $^{\mathrm{o}}$ de Medicina Veterinária, Centro de Ciências Agroveterinárias, UDESC, Lages, SC, Brasil. E-mail: merecav@ yahoo.com.br

* Author for correspondence
} 
os valores hematológicos de tilápias do Nilo (Oreochromis niloticus) submetidas a diferentes anestésicos e amostras obtidas com diferentes anticoagulantes. Foram utilizados trinta peixes, com peso médio de $473 \pm 35,50 \mathrm{~g}$ e comprimento total médio de $29,33 \pm 0,37 \mathrm{~cm}$, adquiridos de piscicultura comercial localizada no município de Lages (SC). Os animais foram divididos aleatoriamente em três grupos $(\mathrm{n}=10)$ conforme a forma de indução: grupo eugenol (GE) na concentração de $70 \mathrm{mg} \mathrm{L}^{-1}$, grupo cloridrato de benzocaína (GB) na concentração de $100 \mathrm{mg} \mathrm{L}^{-1}$ e grupo controle (GC) sem o uso de anestésicos. As amostras de sangue foram obtidas por venopunção dos vasos caudais e acondicionadas em microtubos contendo heparina sódica ou $\mathrm{Na}_{2}$ EDTA e posteriormente processadas. Os resultados foram avaliados pelo Sigma Stat, sendo utilizado o teste-t pareado para dados entre diferentes anticoagulantes pertencentes ao mesmo grupo e análise de variância, seguida de teste de Tukey para comparação das médias entre grupos $(\mathrm{p} \leq 0,05)$. A maioria das alterações observadas no eritrograma foram superiores com o anticoagulante heparina e no grupo benzocaína comparados com o grupo controle. Porém no leucograma, os valores obtidos foram maiores com o anticoagulante $\mathrm{Na}_{2}$ EDTA em todos os grupos, sugerindo que a heparina pode causar aglomeração celular. Baseado nos resultados encontrados conclui-se que os anestésicos testados minimizaram o efeito do estresse causado por manipulações e procedimentos invasivos quando comparado ao grupo controle e a heparina foi o anticoagulante que causou menor hemólise quando comparado com o $\mathrm{Na}_{2}$ EDTA para esta espécie no teste de fragilidade osmótica eritrocitária. Assim, as variações hematológicas a partir de amostras obtidas com diferentes protocolos anestésicos e/ou diferentes anticoagulantes devem ser consideradas para a espécie Oreochromis niloticus.

Palavras-chave: Anestésicos, anticoagulantes, hematologia, fragilidade osmótica, Oreochromis niloticus

\section{Introduction}

Pisciculture requires accurate information about the identification and control of stressful situations and/or illnesses to maximize fish health (TAVARES-DIAS et al., 2000a). Tilapia breeding in the state of Santa Catarina is as an alternative form of income that represents a considerable portion of a fish farmer's profits, whether by the production of adult fish or fingerlings. Tilapia tends to be more resistant to viral, bacterial, and parasitic diseases, in comparison to other farmed fish (SOUZA FILHO et al., 2003).

Clinical hematology, particularly the analysis of blood cell morphology, facilitates the diagnosis of disease and can serve as a prognostic indicator of pathological conditions. However, there is a general lack of consistent information regarding blood sampling in fish. Analysis of hematological parameters can be a quick, practical, and low cost method to identify illness in fish (SATAKE et al., 2009). Selection of the ideal anticoagulant is also an important consideration in hematological analysis, as it can potentially affect the results. Some anticoagulants present limitations during the processing of blood samples, causing in vitro changes that can affect the determination of hematological parameters (WALENCIK; WITESKA, 2007). Occasionally, blood cells may form clots in the presence of the anticoagulant, which can be seen grossly or microscopically as aggregated thrombocytes on the blood smear (HRUBEC; SMITH, 2010).

The focus of several studies in recent years has been the minimization of stress caused by capture. The use of anesthetics in pisciculture is considered vital to reduce the interference of stressors (MOREIRA et al., 2011). According to Zahl et al. (2009), anesthetic efficacy shows both intra- and inter-specific variance. Therefore, fish of the same species of different sizes, ages, and sexes may respond differently to a given concentration of the same anesthetic. These responses can also vary with $\mathrm{pH}$, salinity, temperature, and the level of dissolved oxygen in the water.

Thus, the main objective of the present study was to determine the actions of two anesthetics (benzocaine hydrochloride and eugenol) and different anticoagulants on hematological 
parameters of the species Oreochromis niloticus.

\section{Material and Methods}

The investigation was approved by the Ethics Committee on Animal Experimentation (CETEA) of the Santa Catarina State University (UDESC) under the Protocol 1:26:14.

The study was conducted in the Pisciculture Department and in the Veterinary Clinical Laboratory of the Agroveterinary Science Center (CAV) of the Santa Catarina State University (UDESC). Thirty apparently healthy tilapia (Oreochromis niloticus) were acquired from a commercial farm located in Lages City (Santa Catarina State), having an average weight of $473 \pm 35.50 \mathrm{~g}$ and total length of $29.33 \pm 0.37 \mathrm{~cm}$. After transportation, fish were placed in $300 \mathrm{~L}$ water tanks equipped with a constant aeration system. During the experimental period, water temperature and $\mathrm{pH}$ were evaluated once daily, with the use of a bulb thermometer and $\mathrm{pH}$ meter, respectively. The temperature varied from 23 to $23.5^{\circ} \mathrm{C}$ and the $\mathrm{pH}$ between 6.5 and 7. 5 .

\section{Experimental groups}

The fish were divided into three experimental groups each containing 10 animals as follows:

Control group (CG): physical restraint without the use of anesthetics

Benzocaine group (BG): anesthesia with benzocaine hydrochloride (Sigma Aldrich $\left.{ }^{\circledR}\right)$ (100 $\mathrm{mg} \cdot \mathrm{L}^{-1}$ )

Eugenol group (EG): anesthesia with eugenol (Sigma Aldrich $\left.{ }^{\circledR}\right)\left(70 \mathrm{mg} \cdot \mathrm{L}-^{-1}\right)$

Physical restraint was performed with the aid of dip nets for the removal of individuals from tanks. The fish in the control group were restrained manually by using damp cloths at the head region, rendering each animal motionless until collection was complete. Each fish in the other two groups (BG and EG) were considered anesthetized when its positions in the water became random, with a loss of the righting reflex, without response to external stimuli. Respiratory rates were evaluated before and after anesthetic induction.

The animals were weighed and measured. The total length was defined as the measurement from the mouth to the tip of the tail. The fish were positioned in right lateral decubitus and 0.8 to 1.5 $\mathrm{mL}$ of blood was collected in $3 \mathrm{ml}$ syringes, by caudal vessel venipuncture with sterile hypodermic $21 \mathrm{G}$ needles, previously heparinized or washed with $\mathrm{Na}_{2}$ EDTA.

Blood samples were placed into microtubes (2.0 mL) containing sodium heparin (50 IU) or $\mathrm{Na}_{2}$ EDTA $\left(2 \mathrm{mg} \cdot \mathrm{mL}^{-1}\right)$ anticoagulants. All samples were collected in the early morning hours and were processed for hematological analysis and erythrocyte osmotic fragility.

\section{Laboratory tests}

Samples were transported in a refrigerated cooler to the Veterinary Clinical Laboratory, CAVUDESC, which took about an hour after the first sample collection.

$C B C$

Blood smears were prepared in duplicate and were stained with rapid hematological dye (Fast panotic $L B \AA)$.

The total cell count (erythrocytes, leukocytes, and thrombocytes) was performed by the diluent/dye direct method outlined by Natt and Herrick (1952) in a Neubauer chamber at a dilution of 1:100. The values obtained were multiplied by the applicable conversion factor to obtain values expressed per $\mu \mathrm{L}$ of blood. 
Following the total cell count of nucleated cells (leukocytes and thrombocytes) in the Neubauer chamber, a differential count of leukocytes and thrombocytes was performed in the stained sample, resulting in percentage values, from which the absolute values of each cell group was estimated.

The differential leukocyte counts, evaluation of cell morphology, and thrombocyte counts were performed on blood smears viewed through light microscopy $(1000 \times)$, and counted as 200 cells per slide, thereby establishing a percentage for each cell component.

The packed cell volume was determined by the microhematocrit technique described by Jain (1986). The mean corpuscular volume (MCV) and mean corpuscular hemoglobin concentration (MCHC) were determined by mathematical equations.

The hemoglobin was measured using a commercial kit in a semi-automatic biochemical analyzer (Thermoplate TPAnalyzer Plus ${ }^{\circledR}$ ).

\section{Erythrocyte osmotic fragility (EOF)}

The erythrocyte osmotic fragility test was performed in two stages, immediately after sample collection $(0 \mathrm{~h})$, and at $7 \mathrm{~h}$ post sampling, to mimic prolonged transport time between the point of sample collection and the laboratory.

Dilutions of $\mathrm{NaCl}$ ( $\mathrm{pH}$ 7. 4) were made in series from a $10 \%$ stock solution, as follows: $0.85 \%, 0$. $80 \%, 0.75 \%, 0.70 \%, 0.65 \%, 0.60 \%, 0.55 \%, 0$. $50 \%, 0.45 \%, 0.40 \%, 0.35 \%$, 0. $30 \%$, 0. $25 \%, 0$. $20 \%, 0.10 \%$, and $0.00 \%$, to which $10 \mu \mathrm{L}$ of blood was added per $2.5 \mathrm{~mL}$ of each $\mathrm{NaCl}$ concentration. After $30 \mathrm{~min}$ at room temperature, the tubes were centrifuged at $700 \times \mathrm{g}$ to determine the percentage of hemolysis in each concentration. Absorbance was recorded at a wavelength of $546 \mathrm{~nm}$ in a semiautomatic biochemical analyzer (Thermoplate TPAnalyzer Plus $\left.{ }^{\circledR}\right)$.

The test result was expressed as 50\% hemolysis (H50) in the corresponding $\mathrm{NaCl}$ concentration, calculated from a curve, and adjusted by a generalized linear model for proportions linked by the Probit function (PARPART et al., 1947). After verification of the hemolysis curve (H50), data were analyzed with the software R 3.2. 1 for Windows.

Parametric data were tabulated and analyzed by the Sigma Stat 3.5 software, by applying the paired $\mathrm{t}$ test to compare results within each group (CG, $\mathrm{EG}$, and $\mathrm{BG}$ ), and the one-way analysis of variance (ANOVA) test to compare results between groups. Means, including those of the EOF, were evaluated by the Tukey test at $5 \%$ probability.

\section{Results}

No deaths were recorded during the experimental period. The temperature of the water ranged from 23 to $23.5{ }^{\circ} \mathrm{C}$ and the $\mathrm{pH}$ between 6.5 and 7. 5 . During the acclimatization period of $24 \mathrm{~h}$, physical variables ( $\mathrm{pH}$ and temperature) showed no changes that could affect results.

Induction time in seconds was lower in both anesthetized groups in comparison to recovery time. The recovery time in the eugenol group (EG: 580. $30 \pm 135.72 \mathrm{~s}$ ) was significantly higher than that of the benzocaine group (BG: 427. $10 \pm 182.61 \mathrm{~s}$ ).

The erythrogram is presented in Table 1 . There were no statistical differences in packed cell volume (PCV) among the three groups and between the two anticoagulants. In the control group, the red blood cell count in the heparin sample was significantly higher than that in the $\mathrm{Na}_{2}$ EDTA sample. 
Table 1. Mean values ( \pm standard deviation) of the PCV (packed cell volume), Er (erythrocytes), Hb (hemoglobin), MCV (mean corpuscular volume), MCHC (mean corpuscular hemoglobin concentration) of Oreochromis niloticus divided into 3 groups (each $\mathrm{n}=10$ ); CG- without anesthesia, BG-anesthesia with benzocaine $100 \mathrm{mg} \cdot \mathrm{L}^{-1}$, and EGanesthesia with eugenol $70 \mathrm{mg} \cdot \mathrm{L}^{-1}$ using different anticoagulants.

\begin{tabular}{lcccccc}
\hline \multirow{2}{*}{ Parameters } & \multicolumn{3}{c}{ EDTA } & Heparin \\
\cline { 2 - 6 } & CG & BG & EG & CG & BG & EG \\
\hline PVC (\%) & $29,3 \pm 2,3^{\mathrm{NS}}$ & $34,0 \pm 8,5^{\mathrm{NS}}$ & $32,8 \pm 2,6^{\mathrm{NS}}$ & $29,9 \pm 2,6^{\mathrm{NS}}$ & $33,3 \pm 6,0^{\mathrm{NS}}$ & $32,8 \pm 2,3^{\mathrm{NS}}$ \\
$\mathrm{Er}\left(\mathrm{x} 10^{6} / \mu \mathrm{L}\right)$ & $1,9 \pm 0,3^{\mathrm{a}}$ & $1,9 \pm 0,4^{\mathrm{NS}}$ & $1,80 \pm 0,47^{\mathrm{NS}}$ & $2,22 \pm 0,37^{\mathrm{b}}$ & $1,8 \pm 0,5^{\mathrm{NS}}$ & $1,9 \pm 0,4^{\mathrm{NS}}$ \\
$\mathrm{Hb}\left(\mathrm{g} \mathrm{dL}{ }^{-1}\right)$ & $8,3 \pm 1,0^{\mathrm{NS}}$ & $9,0 \pm 1,9^{\mathrm{a}}$ & $9,0 \pm 1,1^{\mathrm{NS}}$ & $8,5 \pm 1,0^{\mathrm{NS}}$ & $9,7 \pm 1,8^{\mathrm{b}}$ & $8,8 \pm 1,0^{\mathrm{NS}}$ \\
$\mathrm{MCV}(\mathrm{fL})$ & $160,0 \pm 27,2^{\mathrm{a}}$ & $186,7 \pm 89,0^{\mathrm{NS}}$ & $194,2 \pm 58,9^{\mathrm{NS}}$ & $137,1 \pm 19,1^{\mathrm{bA}}$ & $196,6 \pm 58,6^{\mathrm{B}}$ & $178,2 \pm 35,7^{\mathrm{NS}}$ \\
MCHC (\%) & $28,2 \pm 2,3^{\mathrm{NS}}$ & $27,0 \pm 2,1^{\mathrm{NS}}$ & $27,3 \pm 2,7^{\mathrm{NS}}$ & $28,5 \pm 2,2^{\mathrm{NS}}$ & $29,1 \pm 2,1^{\mathrm{NS}}$ & $26,7 \pm 1,8^{\mathrm{NS}}$ \\
\hline AB Different upper case letters in the same line indicate statistically significant differences between groups (relative to CG) \\
abDifferent lower case letters in the same line indicate statistically significant differences between anticoagulants in the same group \\
NS Not significant.
\end{tabular}

The control group showed the lowest hemoglobin values, and the benzocaine group showed the highest. The eugenol group showed significantly higher hemoglobin levels than those of the control group, but significantly lower levels than those of the benzocaine group, with no significant differences among the three groups. Statistically significant differences in hemoglobin values were only observed between anticoagulants in the benzocaine group.

The MCV (mean corpuscular volume) values of the benzocaine and eugenol groups were generally higher in comparison to the control group. However, this difference was not statistically significant. Significant differences in MCV values were noted between the control and benzocaine with heparin groups, and between anticoagulants in the control group.
The absolute numbers of total leukocytes and thrombocytes are presented in Table 2. Among all groups, the total number of leukocytes was significantly higher in the $\mathrm{Na}_{2}$ EDTA anticoagulant samples.

Leukocyte and thrombocyte aggregates were observed during the differential count of the heparin samples.

The EOF was evaluated between the benzocaine and eugenol groups, both of which were compared to the control group. Comparison of anticoagulants within the same group was evaluated in two stages: at $0 \mathrm{~h}$ and $7 \mathrm{~h}$ post sample collection. No significant differences were observed among the three groups; however, significant differences ( $p \leq 0$. 05) were noted in H50 values between anticoagulants and between stages within the same group (Table 3). 
Table 2. Mean values ( \pm standard deviation) of WBCs and thrombocytes in Oreochromis niloticus samples obtained with different anticoagulants; three groups (CG- without anesthesia, BG-anesthesia with benzocaine $100 \mathrm{mg} \cdot \mathrm{L}^{-1}$ and EG- anesthesia with eugenol $\left.70 \mathrm{mg} \cdot \mathrm{L}^{-1}\right)$.

\begin{tabular}{|c|c|c|c|c|c|c|}
\hline \multirow{2}{*}{ Parameters } & \multicolumn{3}{|c|}{ EDTA } & \multicolumn{3}{|c|}{ Heparin } \\
\hline & $\mathrm{CG}(\mathrm{n}=10)$ & $\mathrm{BG}(\mathrm{n}=10)$ & $\mathrm{EG}(\mathrm{n}=10)$ & CG $(n=10)$ & $\mathrm{BG}(\mathrm{n}=10)$ & $\mathrm{EG}(\mathrm{n}=10)$ \\
\hline Total Leuk. $/ \mu \mathrm{L}$ & $\begin{array}{c}49516,8 \pm \\
6945,6^{\mathrm{a}}\end{array}$ & $\begin{array}{c}51345,2 \pm \\
10865,7^{\mathrm{a}}\end{array}$ & $\begin{array}{c}48065,9 \pm \\
11593,5^{\mathrm{a}}\end{array}$ & $\begin{array}{c}42536,9 \pm \\
10333,7^{\mathrm{b}}\end{array}$ & $\begin{array}{c}44329,6 \pm \\
11293,6^{\mathrm{b}}\end{array}$ & $\begin{array}{c}39931,6 \pm \\
11796,7^{b}\end{array}$ \\
\hline Seg. Neutro. $/ \mu \mathrm{L}$ & $\begin{array}{c}19723,0 \pm \\
4675,7^{\mathrm{aA}}\end{array}$ & $\begin{array}{c}27691,90 \pm \\
6611,30^{\mathrm{B}}\end{array}$ & $\begin{array}{c}19137,3 \pm \\
7805,1^{\mathrm{a}}\end{array}$ & $\begin{array}{c}16818,9 \pm \\
6057,6^{\mathrm{b}}\end{array}$ & $\begin{array}{c}24791,59 \pm \\
8853,78^{\mathrm{NS}}\end{array}$ & $\begin{array}{c}17128,6 \pm \\
6860,7^{\mathrm{b}}\end{array}$ \\
\hline Lymphocytes/ $\mu \mathrm{L}$ & $\begin{array}{c}26621,9 \pm \\
3912,6^{\mathrm{a}}\end{array}$ & $\begin{array}{c}19711,1 \pm \\
5501,2^{\mathrm{B}}\end{array}$ & $\begin{array}{c}24944,6 \pm \\
6122,6^{\mathrm{a}}\end{array}$ & $\begin{array}{c}23436,3 \pm \\
4669,8^{\mathrm{a}}\end{array}$ & $\begin{array}{c}16633,3 \pm \\
4080,5^{\mathrm{B}}\end{array}$ & $\begin{array}{c}20088,1 \pm \\
7456,4^{\mathrm{b}}\end{array}$ \\
\hline Eosinophyls/ $\mu \mathrm{L}$ & $\begin{array}{l}141,9 \pm \\
229,8^{\mathrm{NS}}\end{array}$ & $\begin{array}{c}0 \pm \\
0^{\mathrm{NS}}\end{array}$ & $\begin{array}{c}238,6 \pm \\
261,3^{\mathrm{a}}\end{array}$ & $\begin{array}{c}41,2 \pm \\
130,2^{\mathrm{NS}}\end{array}$ & $\begin{array}{c}39,6 \pm \\
125,1^{\mathrm{NS}}\end{array}$ & $\begin{array}{c}0 \pm \\
0^{\mathrm{b}}\end{array}$ \\
\hline Basophyils/ $\mu \mathrm{L}$ & $\begin{array}{c}0 \pm \\
0^{\mathrm{NS}}\end{array}$ & $\begin{array}{l}0 \pm \\
0^{\mathrm{NS}}\end{array}$ & $\begin{array}{c}0 \pm \\
0^{\mathrm{NS}}\end{array}$ & $\begin{array}{c}0 \pm \\
0^{\mathrm{NS}}\end{array}$ & $\begin{array}{c}35,7 \pm \\
112,9^{\mathrm{NS}}\end{array}$ & $\begin{array}{l}0 \pm \\
0^{\mathrm{NS}}\end{array}$ \\
\hline Monocytes/ $\mu \mathrm{L}$ & $\begin{array}{l}3030,1 \pm \\
2219,4^{\mathrm{NS}}\end{array}$ & $\begin{array}{l}3942,2 \pm \\
3619,4^{\mathrm{NS}}\end{array}$ & $\begin{array}{c}3745,6 \pm \\
1664,8^{\mathrm{a}}\end{array}$ & $\begin{array}{l}2281,7 \pm \\
1601,3^{\mathrm{NS}}\end{array}$ & $\begin{array}{l}2829,4 \pm \\
2302,2^{\mathrm{NS}}\end{array}$ & $\begin{array}{c}2714,9 \pm \\
1783,7^{\mathrm{b}}\end{array}$ \\
\hline Thromb $/ \mu \mathrm{L}$ & $\begin{array}{c}34262,7 \pm \\
6142,1^{\mathrm{a}}\end{array}$ & $\begin{array}{c}32888,7 \pm \\
5914,3^{\mathrm{NS}}\end{array}$ & $\begin{array}{c}33118,9 \pm \\
8970,5^{\mathrm{a}}\end{array}$ & $\begin{array}{c}30006,4^{ \pm} \\
8087,5^{\mathrm{b}}\end{array}$ & $\begin{array}{c}31092,1 \pm \\
9545,2^{\mathrm{NS}}\end{array}$ & $\begin{array}{c}30006,6 \pm \\
8333,8^{\mathrm{b}}\end{array}$ \\
\hline
\end{tabular}

${ }^{\mathrm{AB}}$ Different upper case letters in the same line indicate statistically significant differences between groups (relative to CG)

${ }^{a b}$ Different lower case letters in the same line indicate statistically significant differences between anticoagulants in the same group

NS Not significant.

Table 3. Mean values ( \pm standard deviation) of buffered saline concentrations $(\% \mathrm{NaCl})$ corresponding to $50 \%$ hemolysis, and anticoagulation effects of $\mathrm{Na}_{2}$ EDTA $(2 \mathrm{mg})$ and heparin (50 IU) on erythrocyte osmotic fragility in tilapia Oreochromis niloticus; CG- group without anesthesia, BG- anesthesia with benzocaine $100 \mathrm{mg} \cdot \mathrm{L}^{-1}$, and EGanesthesia with eugenol $70 \mathrm{mg} \cdot \mathrm{L}^{-1}$, processed immediately $(0 \mathrm{~h})$ and after $7 \mathrm{~h}$ of storage.

\begin{tabular}{ccccccc}
\hline Parameters & \multicolumn{2}{c}{ CG } & \multicolumn{2}{c}{ BG } & \multicolumn{2}{c}{ EG } \\
\hline $\begin{array}{c}\text { Hemolysis } \\
50 \%\end{array}$ & $0 \mathrm{~h}$ & $7 \mathrm{~h}$ & $0 \mathrm{~h}$ & \multirow{2}{*}{$7 \mathrm{~h}$} & \multirow{2}{*}{$0 \mathrm{~h}$} & \multirow{2}{*}{$7 \mathrm{~h}$} \\
\hline EDTA & $0,38 \pm 0,11^{\mathrm{A}}$ & $0,50 \pm 0,16^{\mathrm{aB}}$ & $0,44 \pm 0,07^{\mathrm{aA}}$ & $0,50 \pm 0,10^{\mathrm{aB}}$ & $0,45 \pm 0,08^{\mathrm{a}}$ & $0,48 \pm 0,08^{\mathrm{NS}}$ \\
Heparin & $0,34 \pm 0,10^{\mathrm{NS}}$ & $0,35 \pm 0,08^{\mathrm{b}}$ & $0,32 \pm 0,07^{\mathrm{bA}}$ & $0,37 \pm 0,10^{\mathrm{bB}}$ & $0,36 \pm 0,04^{\mathrm{b}}$ & $0,41 \pm 0,05^{\mathrm{NS}}$ \\
\hline
\end{tabular}

${ }^{\mathrm{AB}}$ Different upper case letters in the same line indicate statistically significant differences between the times $0 \mathrm{~h}$ and $7 \mathrm{~h}$ post collection, in the same group with the same anticoagulant.

${ }^{a b}$ Different lower case letters in the same column indicate statistically significant differences between anticoagulants in the same group and at the same time. ${ }^{\text {NS }}$ Not significant.

In the control group, statistical differences were noted in the $\mathrm{Na}_{2}$ EDTA anticoagulant samples between stages ( $0 \mathrm{~h}$ and $7 \mathrm{~h}$ ), and between $\mathrm{Na}_{2}$ EDTA and heparin samples $7 \mathrm{~h}$ post collection.

In the benzocaine group, significant differences were noted between stages $0 \mathrm{~h}$ and $7 \mathrm{~h}$ for each anticoagulant, and between anticoagulants at $0 \mathrm{~h}$ and $7 \mathrm{~h}$ post collection. In the eugenol group, samples containing the $\mathrm{Na}_{2}$ EDTA anticoagulant generally showed significantly higher values $0 \mathrm{~h}$ post collection, in comparison to samples containing heparin. Mild to moderate hemolysis was observed in capillary microtube samples containing $\mathrm{Na}_{2}$ EDTA, 1-4 h post collection. 


\section{Discussion}

Water temperature did not vary among the three groups, and most likely did not affect the results. This suggests that the main variables responsible for the anesthetic induction and recovery times were the respective anesthetics (MYLONAS et al., 2005).

Anesthetic recovery time, which includes the time from induction to the return to normal activity, was higher in the EG than in the BG. These findings corroborate those of Costa (2011) and Prince and Powell (2000) who report that this increased time can be beneficial in surgical practice, biometrics, and spawning because these manipulations necessitate relatively long periods of anesthesia after removal of the fish from the anesthetic solution. However, according to Marking and Meyer (1985), the efficacy of an anesthetic depends on a short latency time (about $3 \mathrm{~min}$ ) and fast recovery time (approximately $5 \mathrm{~min}$ ). The average recovery times ranged from 7 to 9 min for benzocaine and eugenol, respectively. Although the induction period is relatively faster than the recovery, the anesthetic induction time for both eugenol and benzocaine was sufficient to obtain the samples and record physical measurements in all fish. Even in the control group, which was not subjected to anesthesia, sample collections were easily performed following manual restraint.

The selected concentrations of eugenol and benzocaine in the present study are the most commonly applied dosages in studies of deep anesthesia, primarily for the Oreochromis niloticus species (DELBON, 2006; FAÇANHA; GOMES, 2005; PEAKE, 1998).

Façanha and Gomes (2005) reported that the anesthetic induction time is prolonged when benzocaine of $100 \mathrm{mg} \cdot \mathrm{L}^{-1}$ is used, but the recovery time is typically within the range considered appropriate for procedures such as recording physical measurements. Ostrensky et al. (2000) concluded that the optimal concentration of benzocaine required to achieve complete anesthesia in O. niloticus is $60 \mathrm{mg} \cdot \mathrm{L}^{-1}$.
The concentration of eugenol $\left(70 \mathrm{mg} \cdot \mathrm{L}^{-1}\right)$ was quite satisfactory for tilapia in the weight range used at $23{ }^{\circ} \mathrm{C}$, which is consistent with the findings Peake (1998), who recommends a dose of approximately $60 \mathrm{mg} \cdot \mathrm{L}^{-1}$ for non salmonids. In addition, Delbon (2006) used concentrations of $60-100 \mathrm{mg} \cdot \mathrm{L}^{-1}$ for anesthesia of tilapia.

Heparin has the disadvantage of forming cellular aggregates in birds (CAMPBELL, 1994; CÂNDIDO, 2008). Our results suggest that the same may have occurred in the present study. Mainwaring and Rowley (1985) also observed cell clumps with heparin use.

In the present study, there were no significant differences in packed cell volume among the groups, the values of which approximated those found by other authors for the same species (ALKAHEM, 1994; TAVARES-DIAS et al., 2000a; TAVARESDIAS; FAUSTINO, 1998; UEDA et al., 1997).

Changes in hemoglobin concentration and hematocrit or red blood cell count after stress may suggest hemoconcentration or hemodilution by osmoregulatory mechanisms (HOUSTON et al., 1996). According to McDonald and Milligan (1997), stress causes hemoconcentration in many freshwater fish, which can be observed by higher hematocrit values. However Peterson (1990) states that the increase in hematocrit is generally observed as a result of swelling of the erythrocyte, decrease in plasma volume, increase in the number of erythrocytes, or a combination of these factors.

Our results for the eugenol group are consistent with those of Wagner et al. (2003), who did not find changes in packed cell volume levels of anesthetized fish with clove oil and tricaine methanesulfonate.

Blood collection with heparin can result in higher values of hematocrit, erythrocytes, and hemoglobin compared to those found in blood collected with $\mathrm{Na}_{2}$ EDTA, for the same animal (TAVARES-DIAS; SANDRIN, 1998). As significant differences in the number of red blood cells also occurred in the 
control group, changes in this parameter cannot be solely attributed to the stress caused by anesthetics.

An increase in the number of erythrocytes can follow a reduction in oxygen levels, caused by a reduction in gill irrigation (LOWE-JINDE; NIIMI, 1983). According to Tort et al. (2002), eugenol does not adversely affect the ability of red blood cells to deliver oxygen. The red cell values reported in the present study were similar to those reported by Allen (1994) and Tavares-Dias and Faustino (1998) in healthy Nile tilapia. Other researchers, such as Alkahem (1994) and Silveira and Rigores (1989), reported lower values for the same species and Gomes et al. (2001) also recorded lower red cell values for Cyprinus carpio. In addition, Azevedo et al. (2006) reported lower values of this parameter in farmed fish specimens kept in association with pigs.

In the control group, MCV values were higher in samples with $\mathrm{Na}_{2}$ EDTA anticoagulant than in those with heparin. The values reported in the present study were similar to those reported by Alkahem (1994), Allen (1994), Bittencourt et al. (2003), Nussey et al. (1995), and Silveira and Rigores (1989). MCV was significantly higher in the benzocaine group compared to the control group with heparin. An increase in the size of red blood cells has also been reported in rainbow trout, Salmo gairdneri, following anesthesia with benzocaine or Tricaine methanesulfonate (MS-222) (SOIVIO; NIKINMAA, 1981). Increases in this parameter indicate that red blood cells have become swollen because of osmotic stress or hypoxemia (NUSSEY et al., 1995). Anesthetics may therefore induce undesirable effects by changing hematological variables (SLADKY et al., 2001; THOMAS; ROBERTSON, 1991; WOODY et al., 2002).

Hemoglobin values were significantly higher in heparin samples, the only significant difference recorded between anticoagulants, in the benzocaine group; suggesting that there was an increase in the oxygen transport capacity of cells to meet the energy demands posed by stress (NIKINMAA et al., 1983). The findings of the present study are consistent with those of Allen (1994) in O. aureus; Nussey et al. (1995) and Tavares-Dias et al. (2000a) in $O$. mossambicus; Tavares-Dias and Faustino (1998) in O. niloticus; and Wepener et al. (1992) in Tilapia sparmanii. However, hemoglobin values in the present study were higher than those found by Lea Master et al. (1990) in Sarotherodon melanotheron, by Silveira and Rigores (1989) in O. aureus, and by Ueda et al. (1997) in O. niloticus.

The mean corpuscular hemoglobin concentration (MCHC) of BG and EG groups showed no significant differences compared to the control group, a finding that was consistent with the results of Alkahem (1994), Nussey et al. (1995), TavaresDias and Faustino (1998), and Ueda et al. (1997). However, the present data were higher than those found by Silveira and Rigores (1989) and lower than those found by Allen (1994) and Bittencourt et al. (2003) for O. niloticus. According to TavaresDias and Faustino (1998), this variation may be due to exogenous factors such as temperature and stress.

Hemoglobin and MCHC values vary both between and within species, and these variations can be attributed to several factors, such as temperature, dissolved oxygen concentrations in the water, seasonal cycle, and nutritional status (NIKINMAA et al., 1983). The differences in methodology of blood sample collection can affect variations in these values, just as the type of anticoagulant used can also be a source of variation in the results (TAVARES-DIAS et al., 2000a).

Absolute WBC values were significantly higher with the use of $\mathrm{Na}_{2}$ EDTA anticoagulant in all groups. These results corroborate those of TavaresDias (2003) for the same species, whereas Ueda et al. (1997) reported lower values.

This statistical difference between anticoagulants is probably not linked to the use of anesthetics, since the control group yielded similar results. The difference could be attributed to individual 
differences, or to the disadvantage of cell clumping in heparin, suggesting that the total leukocyte count in the Neubauer chamber may have been understated with this anticoagulant (CAMPBELL, 1994; CÂNDIDO, 2008). The disparity in results could be due to misidentification caused by colorant failure, through the interference of heparin (TAVARESDIAS, 2003). Heparin may have caused neutrophil clumping, resulting in lower values recorded from blood smears, as was observed for total leukocytes values.

There was a predominance of lymphocytes, followed by neutrophils and monocytes in the differential leukocyte count, similar to that observed by Azevedo et al. (2006), Ezzat et al. (1974), Lea Master et al. (1990), Tavares-Dias and Faustino (1998), Tavares-Dias and Moraes (2004), and Tavares-Dias et al. (2000b). Other authors found a predominance of neutrophils in the differential count (TAVARES-DIAS et al., 2000a; UEDA et al., 1997).

The reason behind this predominance of lymphocytes in fish blood is not very clear. Mononuclear cells (lymphocytes and macrophages) in the tissues prevail in the defense mechanisms of the organism, however, under stress, the number of circulating lymphocytes decreases. Thus, the lymphocytes in fish may be present in inflammation, in humoral responses, and may mediate against a variety of insults (IWAMA; NAKANISHI, 1996).

The lymphocyte count was significantly lower with both anticoagulants in the benzocaine group (BG) in comparison to the control group. Despite the absence of anesthesia, the control group may have experienced acute stress at the time of collection, justifying the increase in lymphocytes for this group with different anticoagulants. At the end of the experiment, an increase in the average absolute values of lymphocytes in the eugenol group ( $\mathrm{p} \leq$ 0 . 05) with $\mathrm{Na}_{2}$ EDTA was noted, suggesting that heparin may have decreased lymphocyte values in the eugenol group.
Eosinophils were scarce in this study, which is consistent with the findings of Ranzani-Paiva et al. (1998), Tavares-Dias and Moraes (2003), and Tavares-Dias et al. (2000a). In addition, TavaresDias (2003) did not report any eosinophils in $O$. niloticus. No significant differences were observed among the three groups, however, higher values in $\mathrm{Na}_{2}$ EDTA samples in the eugenol group were noted, approximating the average percentage values reported by Alkahem (1994), Nussey et al. (1995), and Ueda et al. (1997), but lower than those found by Tavares-Dias and Faustino (1998) in O. niloticus reared in an intensive system.

Basophils were rarely observed and this finding may be due to individual differences. They were reported however in the benzocaine group with heparin anticoagulant, corroborating the results of Ranzani-Paiva et al. (1998), Tavares-Dias and Moraes (2003), and Ueda et al. (1997).

The values of most leukocyte types were higher in the $\mathrm{Na}_{2}$ EDTA samples; however, the statistical significance of this observation was not confirmed. This could possibly be attributed to the action of heparin, which induces cell aggregation, a phenomenon also observed in the aforementioned blood smears. There were no previous reports that studied the effects of the two anticoagulants in the present study for the evaluation of leukocytes in this species.

Thrombocytes have been described as the second most abundant blood cells in fish, after erythrocytes (UEDA et al., 2001). However, in all groups of this study, the number of thrombocytes was lower than the absolute number of leukocytes.

Thrombocytes values were significantly higher only in $\mathrm{Na}_{2}$ EDTA samples of the control and eugenol groups. These values however, were lower than those obtained by Tavares-Dias (2003) and Ueda et al. (1997). According to Tavares-Dias and Moraes (2004), besides interspecific variation, differences in methodology could also be responsible for the wide variation in thrombocyte counts. 
The variations between hematological values in the present study and those reported by other researchers for the same species could be attributed to differences in weight, age, and length of the fish (TAVARES-DIAS et al., 2000b).

The erythrocyte osmotic fragility test (EOF) is one way to measure variations in the resistance of erythrocytes to hemolysis when these cells are exposed to the action of hypotonic saline (PERK et al., 1964).

Many intrinsic and extrinsic factors influence the osmotic fragility of erythrocytes, reflected as a decrease or an increase in various conditions (JAIN, 1986). According to Perk et al. (1964), the osmotic fragility is influenced by factors such as the shape, volume, and size of the erythrocyte, type and amount of hemoglobin, differences in the viscoelasticity of the membranes, as well as chemical composition and structure thereof. According to Parpart et al. (1947), the temperature and $\mathrm{pH}$ of the solutions used in the assay may also influence the results.

At the time of sample collection, the stress due to capture and venipuncture can change the permeability of red blood cells, making them more fragile. Thus, to account for this initial hemolysis, the $0.85 \% \mathrm{NaCl}$ solution was regarded as $0 \%$ hemolysis and the $0.00 \% \mathrm{NaCl}$ solution regarded as maximum occurrence in the hemolysis. This correction was based on the phenomena of increased fragility in hypotonic solutions, in which the concentration of intracellular ions results in rapid cell swelling and subsequent lysis of red blood cells.

In the present study, the statistical differences in EOF evaluation, between anticoagulants and between stages, suggests that erythrocyte osmotic fragility increased when fish were exposed to benzocaine. This can occur because benzocaine blocks sodium channels and reduces the membrane potential (HOLLOWAY et al., 2004). However, a decrease in red blood cell and PCV values in the benzocaine group compared to those of the control group could not be verified.

The differences between anticoagulants in the eugenol group at $0 \mathrm{~h}$ may have occurred because of disordered permeability of the cell membrane due to the use of anesthetics, consistent with observations in other studies on tropical fish species (INOUE et al., 2005; TAVARES-DIAS; SANDRIN, 1998).

The erythrocytes of the Nile tilapia showed changes related to membrane fragility in all groups, with both anticoagulants. However, samples containing $\mathrm{Na}_{2}$ EDTA showed mild to moderate hemolysis from the onset, as observed subjectively in capillary microtubes during hematocrit determination. Furthermore, moderate to severe hemolysis was also observed in samples containing $\mathrm{Na}_{2}$ EDTA, after $7 \mathrm{~h}$ of storage, suggesting that $\mathrm{Na}_{2}$ EDTA may be related to increased membrane fragility in $O$. niloticus. Some authors report that high EDTA concentrations result in higher hemolysis percentages with a dose-dependent effect (ISHIKAWA et al., 2010; WALENCIK; WITESKA, 2007).

Erythrocyte hemolysis was observed with EDTA by Van Vliet et al. (1985) in tilapia, and Walencik and Witeska (2007) in common carp, although the precise role of the anticoagulant in increased fragility requires further investigation. This finding could possibly be attributed to chelation of $\mathrm{Ca}^{2+}$ ions that causes variations in the permeability and stability of the red blood cell membranes (WALENCIK; WITESKA, 2007).

On the other hand, hemolysis was lower but not statistically significant in heparin samples, with similar results to the EOF test. This finding corroborates those described in common carp (WALENCIK; WITESKA, 2007). A similar effect was observed in hybrid catfish when heparin (100 IU) was used, suggesting that heparin is an ideal anticoagulant for performing the osmotic fragility test of erythrocytes in fish (ISHIKAWA et al., 2010). 


\section{Conclusions}

The changes observed in the evaluation of blood cells of the species Oreochromis niloticus with various doses of anesthetics could be attributed to cell clumping caused by heparin and hemolysis caused by EDTA. These effects should be taken into consideration when selecting an anticoagulant, relative to the subject of evaluation.

In order to have a better understanding of the adaptive and physiological mechanisms of the species, further studies are recommended to investigate the effects of EDTA and calcium on fish erythrocyte membrane transport systems, the composition of the cell membrane, osmotic fragility maintenance, and the influence of environmental factors.

\section{Acknowledgments}

The author would like to thank the Santa Catarina State University (UDESC), the CAPES for awarding the scholarship, and teacher Thiago Fabregat, who provided the entire structure for maintenance of the animals during the investigation.

\section{References}

ALKAHEM, H. F. The toxicity of nickel and the effects of sublethal levels on haematological parameters and behaviour of the fish, Orechromis niloticus. Kuwait Journal of Science, Riyadh, v. 21, n. 2, p. 243-52, 1994.

ALLEN, P. Changes in the hematological profile of the cichlid $O$. aureus during acute inorganic mercury intoxication a. Comparative Biochemistry and Physiology Part C: Pharmacology, Toxicology and Endocrinology, New York, v. 108, n. 1, p. 117-121, 1994.

AZEVEDO, T. M. P.; MARTINS, M. L.; YAMASHITA, M. M.; FRANCISCO, C. J. Hematologia de Oreochromis niloticus: comparação entre peixes mantidos em piscicultura consorciada com suínos e pesque-pague no vale do rio Tijucas, Santa Catarina, Brasil. Boletim do Instituto de Pesca, São Paulo, v. 32, n. 1, p. 41-49, 2006.

BITTENCOURT, N. L. R.; MOLINARI, L. M.; SCOARIS, D. O.; PEDROSO, R. B.; NAKAMURA, C. V.; NAKAMURA, T. U.; ABREU FILHO, B. A.; DIAS
FILHO, B. P. Haematological and biochemical values for Nile tilapia Oreochromis niloticus cultured in semiintensive system. Acta Scientiarum, Maringá, v. 25, n. 2, p. 385-389, 2003.

CAMPBELL, T. W. Hematology. In:RITCHIE, B. W.; HARRISON, G. J.; HARRISON, L. R. Avian medicine: principles and application. Lake Worth: Wingers Publishing, 1994. p. 176-198

CÂNDIDO, M. V. Hematologia, bioquímica sérica e nutrição em aves: Cracidae. 2008. Dissertação (Mestrado em Ciências Veterinárias) - Setor de Ciências Agrárias, Universidade Federal do Paraná, Curitiba.

COSTA, L. S. Avaliação de óleo de cravo e benzocaína como anestésicos para juvenis de tilápia nilótica. 2011. Dissertação (Mestrado em Zootecnia) - Universidade Federal de Lavras, Lavras.

DELBON, M. C. Ação da benzocaína e do óleo de cravo sobre parâmetros fisiológicos de tilápia, Oreochromis niloticus. 2006. Dissertação (Mestrado em Aquicultura) Centro de Aquicultura da UNESP. Universidade Estadual Paulista Júlio de Mesquita Filho, Jaboticabal.

EZZAT, A. A.; SHABANA, M. B.; FARGHALY, A. M. Studies on the blood characteristics of Tilapia zilli (Gervais) I. Blood cells. Journal of Fish Biology, Alexandria, v. 6, n. 1, p. 1-12, 1974.

FAÇANHA, M. F.; GOMES, L. C. A eficácia do mentol como anestésico para o tambaqui (Colossoma macropomum). Acta Amazônica, Manaus, v. 35, n. 1, p. 71-75, 2005.

GOMES, L. C.; CHIPPARI-GOMES, A. R.; LOPES, N. P.; ROUBACH, R.; ARAUJOLIMA, C. A. R. Efficacy of benzocaine as an anesthetic in juvenile tambaqui Colossoma macropomum. Journal of World Aquaculture Society, Frankfort, v. 32, n. 4, p. 426-431, 2001.

HOLLOWAY, A. C.; KEENE, J. L.; NOAKES, D. G.; MOCCIA, R. D. Effects of clove oil and MS-222 on blood hormone profiles in rainbow trout Oncorhynchus mykiss, Walbaum. Aquaculture Research, Oxford, v. 35, n. 11, p. 1025-1030, 2004.

HOUSTON, A. H.; DOBRIC, N.; KAHURANANGA, R. The nature of hematological response in fish. Studies on rainbow trout Oncorhyncus mykiss exposed to stimulated winter, spring and summer conditions. Fish Physiology and Biochemistry, Amsterdam, v. 15, n. 4, p. 339-347, 1996.

HRUBEC, T. C.; SMITH, S. A. Hematology of fishes. In: WEISS, D. J.; WARDROP, K. J. Schalm's veterinary hematology. $6^{\text {th }}$ ed. Wiley-Blackwell: Ames, 2010. cap. 126, p. 994-1003. 
INOUE, L. A. K. A.; AFONSO, L.; IWAMA, G.; MORAES, G. Effects of clove oil on the stress response of matrinxã (Brycon cephalus) subjected to transport. Acta Amazonica, Manaus, v. 35, n. 2, p. 145-151, 2005.

ISHIKAWA, M. M.; PÁDUA, S. B.; SATAKE, F.; HISANO, H.; JERÔNIMO, G. T.; MARTINS, M, L. Heparina e Na2EDTA como anticoagulantes para surubim híbrido (Pseudoplatystoma reticulatum $\mathrm{x}$ P. corruscans): eficácia e alterações hematológicas. Ciência Rural, Santa Maria, v. 40, n. 7, p. 1557-1561, 2010. Disponível em: <http://dx.doi.org/10.1590/S010384782010005000113>. Acesso em: 6 maio 2014.

IWAMA, G.; NAKANISHI, T. The fish immune system. London: Academic Press, 1996. 380 p.

JAIN, N. C. Schalm's veterinary hematology. $4^{\text {th }}$ ed. Philadelphia: Lea e Febiger, 1986. 1221 p.

LEA MASTER, B. R.; BROCK, J. A.; FUJIOKA, R. S.; NAKAMURA, R. M. Hematologic and blood chemistry values for Sarotherodon melanotheron and a red hybrid tilapia in freshwater and seawater. Comparative Biochemistry and Physiology, Oxford, v. 97, n. 4, p. 525529, 1990.

LOWE-JINDE, L.; NIIMI, A. J. Influence of sampling on the interpretation of hematological measurements of rainbow trout. Salmo gairdneri. Canadian Journal of Zoology, Chalk River, v. 61, n. 12, p. 396-402, 1983.

MAINWARING, G.; ROWLEY, A. F. The effect of anticoagulants on Blennius pholis L. leucocytes. Comparative Biochemistry and Physiology: part A: Physiology, Swansea, v. 80, n. 1, p. 85-91, 1985.

MARKING, L. L.; MEYER, F. P. Are better fish anesthetics needed in fisheries? Fisheries, La Crosse, v. 10, n. 6, p. 2-5, 1985.

McDONALD, G.; MILLIGAN, L. Ionic, osmotic and acid-base regulation in stress. In: IWANA, G. W.; PICKERING, A. D.; SUMPTER, J. P.; SCHRECK, C. B. (Ed.). Fish stress and health in aquaculture. Cambridge: University Press, 1997. p. 119-144.

MOREIRA, A. G. L.; TEIXEIRA, E. G.; MOREIRA, R. L.; FARIAS, W. R. L. Glicose plasmática em juvenis de tilápia do Nilo anestesiados com óleo de cravo. Revista Brasileira de Saúde e Produção Animal, Salvador, v. 12, n. 3, p. 794-804, jul./set. 2011.

MYLONAS, C. C.; CARDINALETTI, G.; SIGELAKI, I.; POLZONETTI-MAGNI, A. Comparative efficacy of clove oil and 2-phenoxyethanol as anesthetics in the aquaculture of European sea bass (Dicentrarchus labrax) and gilthead sea bream (Sparus aurata) at different temperatures. Aquaculture, Amsterdam, v. 246, n.1, p. 467-481, 2005.
NATT, M. P.; HERRICK, C. A. A new blood diluente for counting the erythrocytes and leucocytes of the chicken. Poultry Science, Savoy, v. 31, n. 4, p. 735-738, 1952.

NIKINMAA, M.; SOIVIO, A.; NAKARI, T.; LINDGREN, S. Hauling stress in brown trout (Salmo trutta): physiological responses to transport in fresh water or salt water, and recovery in natural brackinh water. Aquaculture, Amsterdam, v. 34, n. 1-2, p. 93-99, 1983.

NUSSEY, G.; VAN VUREN, J. H. J.; DU PREEZ, H. H. Effects of coper on the haematological and osmoregulation of the Mozambique tilapia. Comparative Biochemistry and Physiology Part C: Pharmacology, Toxicology and Endocrinology, New York, v. 111, n. 3, p. 369-380, 1995.

OSTRENSKY, A.; BORGHETTI, J. R.; PEDINI, M. Situação atual da Aquicultura brasileira e mundial. In: VALENTI, C. V.; POLI, C. R.; PEREIRA, J. A.; BORGHETTI, J. B. Aquicultura no Brasil bases para um desenvolvimento sustentável. Brasília: CNPQ/Ministério da Ciência e Tecnologia, 2000. p. 354-381.

PARPART, A. K.; LORENZ, P. B.; PARPART, E. R.; GREGG, J. R.; CHASE, A. M. The osmotic resistance (fragility) of human red cells. Journal of Clinical Investigation, Ann Arbor, v. 26, n. 4, p. 636-640, 1947.

PEAKE, S. Sodium bicarbonate and clove oil as potencial anesthetics for nonsalmonid fishes. North American Journal of Fisheries Management, Burnaby, v. 18, n. 4, p. 919-924, 1998.

PERK, K.; FREI, Y. F.; HERZ, A. Osmotic fragility of red blood cells of young and mature domestic and laboratory animals. American Journal Veterinary Research, Schaumburg, v. 25, n. 107, p. 1242-1248, 1964.

PETERSON, M. S. Hypoxia-induced physiological changes in two mangrove swamp fishes: sheepshead minnow, Cyprinodon variegatus lacepede and sailfin molly, Poecilia latipinna (Lesueur). Comparative Biochemistry and Physiology Part A, Fort Pierce, v. 97a, n. 1, p. 17-21, 1990.

PRINCE, A.; POWELL, C. Clove oil as an anaesthetic for invasive field procedures on adult rainbow trout. North American Journal of Fisheries Management, Burnaby, v. 20, n. 4, p. 1029-1032, 2000.

RANZANI-PAIVA, M. J. T.; TABATA, Y. A.; EIRAS, A. C. Hematologia comparada entre diplóides e triploides de truta arco-íris, Oncorhynchus mykiss Walbaum (Pisces, Salmonidae). Revista Brasileira de Zoologia, Curitiba, v. 15, n. 4, p. 1093-1102, 1998. 
SATAKE, F.; PÁDUA, S. B. de; ISHIKAWA, M. M. Distúrbios morfológicos em células sanguíneas de peixes em cultivo: uma ferramenta prognóstica. In: TAVARESDIAS, M. (Org.). Manejo e sanidade de peixes em cultivo. Macapá: Embrapa Amapá, 2009. p. 330-345.

SILVEIRA， R.; RIGORES， C. Características hematológicas normales de O. aureus em cultivo, Revista Latinoamericana de Aquicultura, Havana, v. 39, n. 3, p. 54-56, 1989.

SLADKY, K. K.; SWANSON, C. R.; STOSKOPF, M. K.; LOOMIS, M. R.; LEWBART, G. A. Comparative efficacy of tricaine methanesulfonate and clove oil for use as anesthetics in red pacu (Piaractus brachypomus). American Journal of Veterinary Research, Raleigh, v. 62, n. 3, p. 337-342, 2001.

SOIVIO, A.; NIKINMAA, M. The swelling of erytrocytes in relation to the oxygen affinity of the blood of the rainbow trout, Salmo gairdneri Richardson. In: PICKERING, A. D. (Ed.). Stress and fish. London: Academic Press, 1981. p. 197-221.

SOUZA FILHO, J.; SCHAPPO, C. L.; TAMASSIA, S. T. J.; BORCHARDIT, I. Estudo de competitividade da piscicultura no Vale do Itajai. Florianópolis: Instituto Cepa/SC/Epagri/Acaq., 2003. 76 p.

TAVARES - DIAS, M.; FAUSTINO, C. D. Parâmetros hematológicos da tilápia-do-Nilo Oreochromis niloticus (Cichlidae) em cultivo extensivo. Ars Veterinária, Jaboticabal, v. 14, n. 3, p. 254-263, 1998.

TAVARES-DIAS, M. Variáveis hematológicas de teleósteos brasileiros de importância zootécnica. 2003. Tese (Doutorado em Aquicultura) - Centro de Aqüicultura. Universidade Estadual Paulista, Jaboticabal.

TAVARES-DIAS, M.; FRASCÁ-SCORVO, C. M. D.; NOVATO, P. F. C.; MORAES, F. R. Hematological characteristics of hybrid Florida red tilapia, Oreochromis urolepis hornorun x O. mossambicus under intensive rearing. In: INTERNATRIONAL SYMPOSIUM ON TILAPIA AQUACULTURE, 5., 2000, Rio de Janeiro. Anais... Rio de Janeiro: Fitzsimmons, K \& Carvalho Filho, 2000a. p. 533-541.

TAVARES-DIAS, M.; MORAES, F. R. Características hematológicas de Tilapia rendalli Boulenger, 1896 (Osteichthyes: Cichlidae) capturada em "pesque-pague" de Franca, São Paulo, Brasil. Bioscience Journal, Uberlândia, v. 19, n. 1, p. 107-114, 2003.

TAVARES-DIAS, M.; MORAES, F. R. Hematologia de peixes teleósteos. Ribeirão Preto: Lillimpress Complexo Gráfico, 2004. 144 p.

TAVARES-DIAS, M.; SANDRIN, E. F. S. Influence of anticoagulants and blood storage on hematological values in tambaqui, Colossoma macropomum. Acta Scientiarum, Maringá, v. 20, n. 2, p. 151-155, 1998.

TAVARES-DIAS, M.; SCHALCH, S. H. C.; MARTINS, M. L.; MORAES, F. R. Características hematológicas de Oreochromis niloticus (Osteichthyes: Cichlidae) cultivadas intensivamente em pesque-pague do município de Franca, São Paulo, Brasil. Ars Veterinária, Jaboticabal, v. 16, n. 2, p. 76-82, 2000b.

THOMAS, P.; ROBERTSON, L. Plasma cortisol and glucose stress responses of red drum (Sciaenops ocellatus) to handling and shallow water stressors and anesthesia with MS-222, quinaldine sulfate and metomidate. Aquaculture, Amsterdam, v. 96, n. 1, p.6986, 1991.

TORT, L.; PUIGCERVER, M.; CRESPO, S.; PADRÓS, F. Cortisol e haematological response in sea bream and trout subjected to anaesthetics clove oil and 2phenoxyethanol. Aquaculture Research, Chicester, v. 33, n. 11, p. 907-910, 2002.

UEDA, I. K.; EGAMI, M. I.; SASSO, W. S.; MATUSHIMA, E. R. Cytochemical aspects of the peripheral blood cells of Oreochromis (Tilapia) niloticus. (Linnaeus, 1758) (Cichlidae, Teleostei) - Part II Brazilian Journal of Veterinary Research and Animal Science, São Paulo, v. 38, n. 6, p. 273-277, 2001.

Estudos hematológicos em Oreochromis

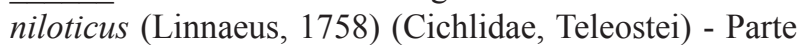
I. Brazilian Journal of Veterinary Research and Animal Science, São Paulo, v. 34, n. 5, p. 270-275, 1997.

VAN VLIET, K. J.; SMIT, G. L.; PIETERSE, J. J.; SCHOONBEE, H. J.; VAN VUREN, J. H. J. The effects of generally used anticoagulants on the haemolysis of fish erythrocytes. Water $S A$, Pretoria, v. 2, n. 2, p. 87-92, 1985.

WAGNER, G. N.; SINGER, T. D.; McKINLEY, R. S. The ability of clove oil and MS-222 to minimize handling stress in rainbow trout (Oncorhynchus mykiss Walbaum). Aquaculture Research, Malden, v. 34, n. 13, p. 1139-1146, 2003.

WALENCIK, J.; WITESKA, M. The effects of anticoagulants on hematological indices and blood cell morphology of common carp (Cyprinus carpio L.). Comparative Biochemistry and Physiology: Part C: Toxicology and Pharmacology, New York, v. 146, n. 3, p. 331-335, 2007.

WEPENER, V.; VUREN, J. H. J.; PREEZ, H. H. The effect of manganese and iron at a neutral and acid $\mathrm{pH}$ on the haematology of the banded tilapia (Tilapia sparrmanii). Bulletin of Environmental Contamination and Toxicology, New York, v. 49, n. 4, p. 613-619, 1992. 
WOODY, C. A.; NELSON, J.; RAMSTAD, K. Clove oil as an anaesthetic for adultsockeye salmon: field trails. Journal of Fish Biology, New York, v. 60, n. 2, p. 340-347, 2002. Available at: <http://onlinelibrary.wiley. com/>. Accessed at: 23 mar. 2014.
ZAHL, I. H.; KIESSLING, A.; SAMUELSEN, O. B.; HANSEN, M. K. Anaesthesia of Atlantic cod (Gadus morhua) - effect of pre-anaesthetic sedation, and importance of body weight, temperature and stress. Aquaculture, Amsterdam, v. 295, n. 1-2, p. 52-59, 2009. 